\title{
WILLINGNESS OF HIGH SCHOOL STUDENTS TO BE TREATED BY AN HIV INFECTED HEALTH PRACTITIONER. A STUDY DONE IN DAR ES SALAAM, TANZANIA.
}

- By: Kimambo Alex (DDS5 MUHAS-2008/09)

\section{ABSTRACT}

\section{OBJECTIVE}

To assess willingness of high school students to be treated by HIV/AIDS infected dental practitioners in Ilala municipality, Dar Es Salaam, Tanzania.

\section{METHODOLOGY}

This was a descriptive cross-sectional study.

\section{RESULTS}

More than half (52.8\%) of the high school students showed fear of being treated by HIV/AIDS infected dental practitioner, with 175 (55.4\%) out of 316 students fearing even to be clinically examined by HIV positive dental practitioner. Out of 316 students, $163(51.6 \%)$ students showed no problem in consulting a HIV/AIDS infected dental practitioner for dental problems. There were 170 (53.8\%) respondents who were uncomfortable to undergo dental treatment provided by HIV positive dental practitioner.

\section{CONCLUSION}

The results of this study showed that there is fear an element of negative attitude and stigmatization among high school students on being treated by HIV/AIDS infected health care practitioner.

\section{INTRODUCTION}

According to the most recent statistics, more than 40 million people in the world are living with HIV/AIDS. Approximately 37.5 million of these individuals are adults and 2.5 million are children. It was estimated that 5 million people were infected with the HIV virus in 2003. Despite worldwide HIV prevention efforts, there are higher numbers of individuals living with HIV today than there have been in the last 5 years ${ }^{1}$.

From the beginning, the HIV/AIDS epidemic has been accompanied by an epidemic of fear, ignorance and denial leading to stigmatization and discrimination of people living with HIV/AIDS and their family members. ${ }^{2}$ Fear of being identified with HIV prevents people from learning their serostatus, changing unsafe behaviour, and caring for people living with HIV/AIDS. An ICRW study in Botswana and Zambia found that stigma against HIV-positive people and fear of mistreatment prevented people from participating in voluntary counselling and testing (VCT) and programs to prevent mother-to-child transmission (MTCT) ${ }^{3}$.
Studies in African countries estimate AIDS causes between $19 \%$ and $53 \%$ of Government heath employee deaths ${ }^{4}$. Malawi and Zambia which are among the southern African countries have experienced five to six fold increases in health care related illness death rates. $^{5}$

Although HIV infected health care workers including dentist have been identified in the past, proven HIV transmission to patients is very rare. Most authorities recommend that an HIV positive health care worker be monitored by an expert panel, which could then if necessary refer to the regulatory body to revoke or restrict the person's license to practice. ${ }^{6}$ Mandatory HIV test is not required for health care worker because they generally do not pose a risk for infecting their patients, they are however ethically and legally obligated to report their HIV status to their profession's regulatory body. ${ }^{6}$

There have been a large number of look-back studies involving patients of HIV-positive health care workers ${ }^{7}$ but only 2 showed probable transmissions. 
In one review, 22171 HIV test results for patients were available for 51 of 64 HIV positive health care workers ( 29 were dentists or dental students) ${ }^{7}$.Only 5 of 113 HIV-positive patients was found to have no identifiable risk factors for HIV infection. HIV isolates were available for 3 of the 5 patients; however, the isolates differed from those of their health care workers. The US Centers for Disease Control and Prevention (CDC) concluded that, although there is a risk of transmission from a health care worker to a patient, the risk is small. ${ }^{8}$

In 1990 and 1991 the center for disease control and prevention-CDC published details of the possible transmission of HIV from an infected dentist in Florida, ${ }^{8,9}$ to 6 former patients, none of whom had other appreciable risk factors for HIV infection 10,11 A comparison of HIV strains from the patients and the dentist was highly suggestive that the strains were identical ${ }^{12,13}$. There was criticism of the CDC's traditional and molecular, epidemiologic investigations, but an independent analysis of the molecular data verified the CDC's findings ${ }^{14,15}$.The infected patients recalled that the dentist wore gloves and a mask during visits, and neither the patients nor the $C D C$ investigators noted evidence of significant breaches of infection control procedures. Patient-topatient transmission of HIV through infected dental instruments was considered unlikely ${ }^{16}$.Thus, although dentist-to-patient transmission was likely in these cases, the mode of transmission is unknown.

Again, in the study done by Ou et al, seven patients became infected by HIV without any previous risks factors for HIV infection but had undergone invasive dental treatment under HIV infected dentist. Comparative genetic analysis and epidemiological investigations indicated that the patient became infected with HIV while receiving care from a dentist with HIV/AIDS ${ }^{16}$ Survey indicates that there is a great deal of confusion and fear among the public on cross infection in dental clinic, which needs to be addressed properly through health education campaign. ${ }^{17}$

another study by Irigoyen-Camacho et al shows that only $20 \%$ of the 490 participants were ready to continue with treatment after knowing that the dentist is HIV positive ${ }^{18}$.
With regard to the above reports, it appears that a possibility exist for transmission of HIV from dentistto-patient. This can be one of the reasons for fear, stigma and discrimination. Therefore this study is designed to assess these reasons among high school students, in Ilala municipality, Dar es Salaam

Similar studies done in this country could not be retrievable. Therefore this study is of much use to the dentists, health care providers as well as the countries policy makers on how to address this problem in our country.

The study provides some clues on the reasons for fear, stigma and discrimination of HIV/AIDS person.

\section{METHODOLOGY}

This study was a descriptive cross-sectional study conducted at Tambaza and Benjamin Mkapa High Schools in Ilala municipality (Dar Es Salaam), which involved a total of 316 students randomly sampled among individuals with a relatively good understanding of HIV/AIDS transmission. The information was obtained through interview using a swahili structured questionnaire which measured students' attitude, fear, stigma and discrimination towards HIV positive dental practitioner. Data obtained were analyzed using SPSS version 11.5 computer program and the results were tabulated. Verbal consent was obtained from the research participants before inclusion into the study.

\section{RESULTS}

Table 1. Distribution of Participants by their attitudes towards HIV infected dental practitioner

\begin{tabular}{|l|l|l|l|}
\hline PROCEDURE & AGREE & DISAGREE & NOT SURE \\
\hline Consultation & $163(51.6)$ & 103(32.6) & 50(15.8) \\
\hline $\begin{array}{l}\text { Has Lost self } \\
\text { esteem }\end{array}$ & $59(18.7)$ & 207(65.5) & 50(15.8) \\
\hline $\begin{array}{l}\text { He is Emotionally } \\
\text { unstable }\end{array}$ & $90(28.5)$ & $174(55.1)$ & $52(16.5)$ \\
\hline $\begin{array}{l}\text { Unfit to extract } \\
\text { teeth }\end{array}$ & $52(16.5)$ & $211(66.8)$ & $53(16.8)$ \\
\hline $\begin{array}{l}\text { Should not } \\
\text { perform Minor } \\
\text { surgery }\end{array}$ & $86(27.2)$ & $194(61.4)$ & $36(11.4)$ \\
\hline $\begin{array}{l}\text { Should not } \\
\text { perform Major } \\
\text { surgery }\end{array}$ & $121(38.3)$ & $164(51.9)$ & $31(9.8)$ \\
\hline
\end{tabular}


More than half (51.6\%) of the students were willing to consult an HIV infected dental practitioner for dental treatment.

Table 2: Distribution of participant by fear towards dental procedures

\begin{tabular}{|l|l|l|l|}
\hline PROCEDURE & FEARFUL & NOT FEARFUL & NOT SURE \\
\hline $\begin{array}{l}\text { Clinical } \\
\text { examination }\end{array}$ & $175(55.4)$ & $125(39.6)$ & $16(5.1)$ \\
\hline Cleaning teeth & $174(55.1)$ & $112(35.4)$ & $30(9.5)$ \\
\hline Restoration & $160(50.6)$ & $98(31.0)$ & $58(18.4)$ \\
\hline Extraction & $186(58.9)$ & $95(30.1)$ & $35(11.1)$ \\
\hline Major operation & $192(60.8)$ & $81(25.6)$ & $43(13.6)$ \\
\hline
\end{tabular}

Clinical examination which is regarded as a non invasive procedure was feared by more than half (55.4\%) of the students.

Table 3: Distribution of participants by Stigma

\begin{tabular}{|l|l|l|}
\hline STIGMA & $\begin{array}{l}\text { NUMBER OF } \\
\text { STUDENTS }\end{array}$ & PERCENTAGE \\
\hline Present & 170 & 53.8 \\
\hline Absent & 146 & 46.2 \\
\hline Total & 316 & 100.0 \\
\hline
\end{tabular}

The table above shows that, more than half of the students (53.8\%) are likely to stigmatize the HIV/AIDS dental practitioner.

Table 4: Distribution of Participants by their response whether they were comfortable with dental procedures

\begin{tabular}{|l|l|l|l|}
\hline $\begin{array}{l}\text { DENTAL } \\
\text { PROCEDURE }\end{array}$ & AGREE & DISAGREE & $\begin{array}{l}\text { NOT } \\
\text { SURE }\end{array}$ \\
\hline Examination & $106(33.5)$ & $167(52.8)$ & $43(13.6)$ \\
\hline Restoration & $102(32.3)$ & $166(52.5)$ & $48(15.2)$ \\
\hline Teeth cleaning & $119(37.7)$ & $156(49.4)$ & $41(13.0)$ \\
\hline Major Operation & $77(24.4)$ & $174(55.1)$ & $65(20.6)$ \\
\hline
\end{tabular}

Majority (55.1\%) of the student were not comfortable to undergo major operation under HIV positive dental practitioner.

A total 316 students who filled the questionnaires, table 2 shows the assessment of fear among high school students on being treated by an HIV/AIDS infected dental practitioner. More than half of the students $(52.8 \%)$ showed fear in all dental procedures with majority fearing major operations (60.8\%), followed by dental extraction which were $58.9 \%$. Clinical examination which is regarded as nonaggressive procedure was also feared by $(55.4 \%)$ of the students. Cleaning of the teeth was feared by $55.1 \%$ of the respondents in total while tooth filling/ restoration was feared by $50.6 \%$.

The results shows that students attitudes towards a HIV/AIDS infected dental practitioner is not bad with 163 students (51.6\%) showing no problem as regarding to consulting a HIV/AIDS infected dental practitioner for a dental problem. Majority $(66.8 \%)$ of the students disagree with the notion that HIV positive dental practitioner is unfit to do dental extractions. Only $28.5 \%$ of the students in total agreed that HIV positive dental practitioner is emotionally unstable contrary to $55.1 \%$ who disagreed that HIV positive dental practitioner is emotionally unstable.

Among the students who responded to the question as to whether HIV positive dental practitioner should not perform major operations $24.4 \%$ Agreed while 55.1\% disagreed. Stigma and discrimination was present in $53.8 \%$ of the students as shown in table 3.0.Among the students $33.5 \%$ were comfortable to let their mouths be clinically examined by HIV positive dental practitioner; however $52.8 \%$ were not comfortable as shown in Table 3.1.

\section{DISCUSSION}

This study explored participants feelings related to HIV positive practitioner and routine dental practice. Ideas generated from this shed light on what patients feel in the event of being treated by an HIV positive practitioner. Globally the HIV/AIDS pandemic has left many countries distabilized in various sectors including the health sector. Usually fear, stigma and discrimination accompanies HIV/AIDS in most cases, this increases the possibility of interfering with the health care delivery system and this is what made this study important. Negative attitude and discrimination towards medical and dental practitioners can have negative impact to health sectors especially in African countries where there is scarcity of health personnel.

However this study shows that students' attitude towards HIV positive dental practitioner is good. More than half (51.6\%) of the students were ready to consult HIV positive dental practitioner for a dental problem. Discrimination of infected dental practitioner 
which accompanies HIV infection was also observed to more than half $(53.8 \%)$ of the participants. This was expected to be a little low since the subjects were high school students who have the knowledge on HIV transmission.

In assessing stigmatization among high school students, more than half $(53.8 \%)$ of the participants showed stigma towards HIV positive dental practitioner, since that percentage $(53.8 \%)$ of the students were not comfortable to undergo dental procedures under HIV positive dental practitioner. Even though there is no much freedom for a patient to choose the kind of doctor he/she wants to be attended by, the World Medical Association (WMA) mentions that the patient has the right to choose his/her physician freely and he/she has the right to accept or refuse treatment after receiving adequate information. For most of the African countries the patients can not use this right of choosing their physician simply because there is no policy that forces the medical or dental practitioner for this matter to disclose his/her HIV/ AIDS status when there is a suspicion to endanger patient's life.

Close observation has shown that the chances of HIV transmission in the dental clinic when all the precautions of infection control were observed are very minimal. However studies have proved that there have been patients who acquired HIV infection when attending dental treatments under HIV-positive dentists.

In this study, more than half (55.4\%) of 316 students feared even to undergo clinical examination under HIV positive dental practitioner. The fact that this study targeted high school students who have the knowledge about HIV transmission gives us the picture of what could be the results if similar study is conducted in the general community.

\section{CONCLUSION}

The results obtained from this study showed that there was fear, stigmatization and elements of negative attitude among high school students regarding being treated by HIV/AIDS infected dental practitioner.

\section{RECOMMENDATIONS}

This kind of study should be expanded to reach the general community so as to obtain the real picture of their perception concerning their willingness to be treated by a HIV/AIDS infected dental practitioner. There is a need for the ministry of health to revise the health policy in the view of HIV/AIDS problem particularly the patient doctor relationship and their rights in the future. It is about time that we conduct an open-public discussion on the subject of HIV/AIDS and its implication to both the health care providers and health care receiver.

\section{REFERENCES}

1. United Nations Joint Program HIV/AIDS (UNAIDS) and World Health Organization (WHO). AIDS Epidemic Update, 2003.

2. Herek, G. and E.K. Glunt. 1988. "An epidemic of stigma: public reaction to AIDS." American Psychologist 43(11): 886-891.

3. Nyblade, L. and M. L. Field. 2000. Women, Communities, and the Prevention of Mother-to-Child Transmission of HIV: Issues and Findings from Community Research in Botswana and Zambia. Washington, DC: ICRW.

4. Tawfik L, Kinoti S, 2001; The Impact of HIV/AIDS on Health Sector Sub Saharan Africa.

5. J.M.Macintosh, University of Victoria, BC, Canada. Challenging an epidemic of stigma. Abstract, journal of AIDS society. www.AIDS 2004.org

7. Michael $A$ et al; The HIV-positive dentist, Balancing the rights of the health care worker and the patient, University of Toronto and faculty of law, Queens University, Kingstone, CMJ, June 12, 2001:164 (12)

8. Robert $L M$, Chamberland ME, Cleveland JL, Marcus R, Gooch BF, Srivastava PU, et al. Investigations of patients of health care workers infected with HIV. The Centers for Disease Control and Prevention Database. Ann Intern Med1995; 122:653-7. 
9. Centers for Disease Control. Possible transmission of human immunodeficiency virus to a patient during an invasive dental procedure. MMWR 1990; 39:489-93

10. Centers for Disease Control. Update: investigations of persons treated by HIV infected health-care workers United States. MMWR 1993; 42:329-31.

11. Ciesielski C, et al., Transmission of human immunodeficiency virus in a dental practice. Ann Intern Med 1992; 116:798-805.

12. Ou CY, Ciesielski CA, Myers G, Bandea CI, Luo CC, Korber BTM, et al.Molecular epidemiology of HIVtransmission in a dental practice. Science 1992; 256:1165-71.

13. Barr S. The 1990 Florida dental investigation: Is the case really closed? Ann InternMed 1996; 124:250-4

14. Temple FS, Waterman MS. The continuing case of the Florida dentist. Science 1992; 256:1155-6

15. Gooch B, Marianos D, Ciesielski C, Dumbaugh R, Lasch A, Jaffe A, et al. Lack of evidence for patient-to-patient transmission of HIV in a dental practice. J Am Dent Assoc 1993; 124:38-44

16. Lanchard A, Ferris S, Chamaret S, Guetard D, Montagnier L. Molecular evidence for nosocomial transmission of human immunodeficiency virus from a surgeon to one of his patients. J Virol 1998; 72:4537-40.

17. Lot F, Seguier JC Fegueux S, Astagneau P, Simon P, Aggoune $M$, et al. Probable transmission of HIV from an orthopedic surgeon to a patient in France. Ann Intern Med 1999; 130:1-65

18. Samaranayake LP, Mc Donald KC.Patient perception of cross infection prevention in dentistry. Oral Surgery and Oral Pathology.1990 Apr; 69(4):457-60

19. Irigoyen-Camacho ME, Zepeda-Zepeda MA, Maupome G, Lopez Camara V. Infection Control.2003 Jun; 31(4):231-6. 